\title{
Increased Intestinal Permeability and Decreased Barrier Function: Does It Really Influence the Risk of Inflammation?
}

\author{
Hiroshi Fukui \\ Department of Gastroenterology, Endocrinology and Metabolism, Nara Medical University, Kashihara, Japan
}

\begin{abstract}
Key Words
Intestinal permeability · Endotoxemia · Inflammatory bowel disease - Irritable bowel syndrome - Liver disease · Acute pancreatitis - Chronic kidney disease $\cdot$ Chronic heart failure . Depression
\end{abstract}

\begin{abstract}
Background: Increased intestinal permeability due to barrier dysfunction is supposed to cause microbial translocation which may induce low-grade inflammation in various diseases. However, this series of events has not been comprehensively evaluated yet. Summary: Intestinal epithelial barrier dysfunction and increased permeability have been described in patients with inflammatory bowel disease (IBD), irritable bowel syndrome (IBS), alcoholic liver disease, nonalcoholic steatohepatitis (NASH), liver cirrhosis, acute pancreatitis, primary biliary cholangitis (PBC), type 1 and type 2 diabetes, chronic kidney disease, chronic heart failure (CHF), depression, and other diseases. Most clinical reports used either permeability assays of challenge tests or measurement of circulating bacterial markers like endotoxin for assessment of 'the leaky gut'. The intestinal permeability assessed by the challenge tests has often been related to the changes of tight junction proteins in the epithelium or circulating endotoxin levels. In patients with IBD, alcoholic liver disease, $\mathrm{NASH}$, liver cirrhosis, PBC, obstructive jaundice, severe acute pancreatitis, and $\mathrm{CHF}$, endotoxemia and proinflammatory
\end{abstract}

cytokinemia have been found in addition to increased permeability. In the serum of patients with IBS and depression, antiflagellin antibodies and antilipid $A$ antibodies were detected, respectively, together with increased permeability and proinflammatory cytokinemia. The site of infection, which is localized to the intestine in IBD and IBS, includes various extraintestinal organs in other diseases. The relation of gut dysbiosis to intestinal barrier dysfunction has gradually been clarified. Key Messages: Although no direct causeand-effect relationship has been confirmed, all clinical and experimental data suggest the importance of intestinal hyperpermeability in the inflammatory changes of various diseases. Increased intestinal permeability is a new target for disease prevention and therapy. Considering the close relationship of 'the leaky gut' and gut dysbiosis to the major diseases, we can conclude that meticulous dietetic and probiotic approaches to recover healthy microbiota have the potential to make a breakthrough in the management of these diseases tomorrow.

(c) 2016 S. Karger AG, Basel

\section{Introduction}

Intestinal barrier prevents the entry of pathogenic microorganisms and toxic luminal substances while regulating the absorption of nutrients, electrolytes and water from the lumen into the circulation [1]. These functions

\section{KARGER}

E-Mail karger@karger.com

www.karger.com/iid (c) 2016 S. Karger AG, Basel

2296-9403/16/0013-0135\$39.50/0
Hiroshi Fukui

Department of Gastroenterology, Endocrinology and Metabolism Nara Medical University

840 Shijo-cho, Kashihara, 634-8522 Nara (Japan)

E-Mail hfukui@naramed-u.ac.jp 
Fig. 1. The diseases in which increased intestinal permeability has been reported in the literature. Intestinal epithelial barrier dysfunction and increased permeability allow the translocation of bacteria and microbial products, which may induce inflammatory changes in the target organs. The 'leaky gut hypothesis' seems to be a reasonable explanation of the pathophysiological background of various diseases. PSC $=$ Primary sclerosing cholangitis.

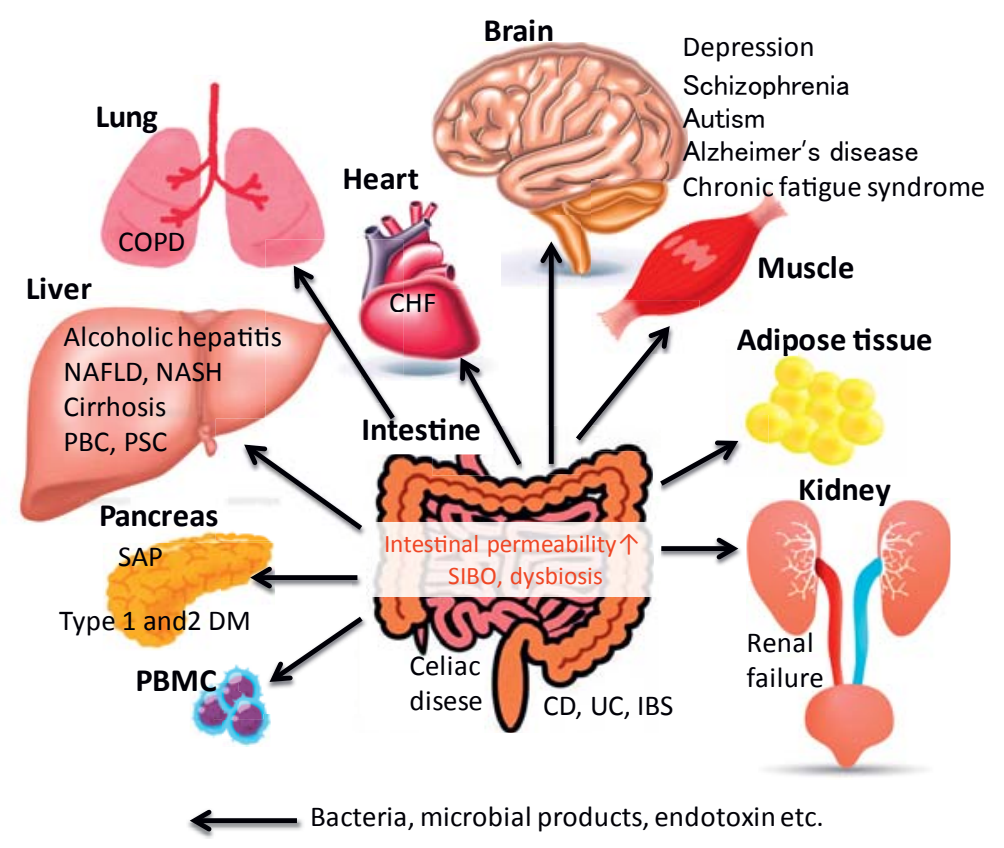

are preserved by a complex multilayer system, consisting of an external physical barrier and an inner functional immunological barrier [2]. From a structural perspective, this multilayer system includes a mucus layer and a monolayer of epithelial cells interconnected by tight junctions (TJs). Intestinal permeability is a functional feature of the intestinal barrier measurable by analyzing flux rates of inert molecules across the intestinal wall, which was precisely defined by the consensus in an expert panel in Frankfurt/Germany in June 2012 [2]. An intact intestinal barrier prevents the permeation of antigens, endotoxins, pathogens, and other proinflammatory substances into the human body, whereas intestinal disintegrity allows their entry, which may trigger local or systemic inflammation and disease [3]. Assessment of intestinal barrier function and permeability in humans is currently possible by using intestinal permeability assays, and by the assessment of biomarkers of epithelial integrity such as soluble adhesion molecules, other biomarkers of immunity or inflammation, or bacterial markers like circulating endotoxin. Most clinical reports used either permeability assays of challenge tests or measurement of circulating bacterial markers like endotoxin [2]. It should be noted that the mechanisms determining the flux of challenged substance and the translocation of bacteria or their products are different, which presents a limitation to the intestinal permeability assays. Therefore, the detection of gut-derived microbial products in the circulation is considered as a definite evidence of increased intestinal permeability. In addition, histological approaches and scanning electron microscopy analyses of the intestinal mucosa have been used in experimental settings [2]. The minute mechanism of this gastrointestinal barrier and variable evaluation methods of gut permeability have been described in detail in a previous review [2].

Intestinal epithelial barrier dysfunction and increased permeability have been described in many human diseases, including inflammatory bowel disease (IBD), irritable bowel syndrome (IBS), alcoholic liver disease, nonalcoholic fatty liver and steatohepatitis, liver cirrhosis, severe acute pancreatitis (SAP), primary biliary cholangitis (PBC), type 1 and type 2 diabetes, depression, and more, as presented in figure 1. The 'leaky gut hypothesis' explains that the intestinal barrier dysfunction induces the chronic low-grade inflammation in various target organs by virtue of microbial products. This review discusses clinical and experimental evidence linking gut permeability and inflammation in various diseases to find out whether increased intestinal permeability and decreased barrier function really influence the risk of inflammation. Clinical evidence on the permeability tests, intestinal ep- 
Table 1. Clinical evidence on the permeability tests, intestinal epithelial changes, circulating microbial products and inflammatory changes of the target organs in various diseases

\begin{tabular}{|c|c|c|c|c|}
\hline Diseases & Permeability test & $\begin{array}{l}\text { Intestinal epithelial } \\
\text { changes }\end{array}$ & Microbial products in the blood & $\begin{array}{l}\text { Inflammatory changes in various } \\
\text { organs }\end{array}$ \\
\hline IBD & $\begin{array}{l}\text { IP } \uparrow \text { in } \mathrm{CD} \text { (L/M test) [4] } \\
\mathrm{IP} \uparrow \text { in } \mathrm{CD} \text { (active }>\text { inactive) } \\
\text { (L/M test) [6] } \\
\mathrm{IP} \uparrow \text { in inactive UC (L/M test) } \\
{[7]} \\
\mathrm{IP} \uparrow \text { in } 50 \% \mathrm{CD} \text { and } 31 \% \mathrm{UC} \\
\text { (iohexol test) [8] }\end{array}$ & $\begin{array}{l}\text { Expression of } \operatorname{PrP}(\mathrm{c}) \downarrow \text { in } \\
\text { the colonic epithelia from } \\
\mathrm{CD} \text { and UC patients [9] }\end{array}$ & $\begin{array}{l}\text { Endotoxemia }(+) \text { in } 28 \sim 88 \% \\
\text { active UC and } 48 \sim 94 \% \text { active } \\
\text { CD }[10,11] \\
\text { Endotoxemia }(+) \text { correlated } \\
\text { with disease activity, disease } \\
\text { extent and plasma TNF }[10]\end{array}$ & $\begin{array}{l}\text { Serum LBP and sCD } 14 \uparrow \text { correlated } \\
\text { with disease activity and } \\
\text { proinflammatory cytokines [11] }\end{array}$ \\
\hline IBS & $\begin{array}{l}\text { IP } \uparrow \text { especially in PI-IBS and } \\
\text { D-IBS [15] } \\
\text { IP } \uparrow \text { associated with IBS } \\
\text { interference with activities and } \\
\text { work, anxiety and depression } \\
\text { (L/M test) [16] }\end{array}$ & $\begin{array}{l}\text { ZO-1 expression } \downarrow \\
\text { correlated with increased } \\
\text { paracellular IP [17] } \\
\text { ZO- } 1 \text { and occludin } \\
\text { expression } \downarrow[18]\end{array}$ & $\begin{array}{l}\text { Anti-flagellin antibodies (+) in } \\
\text { ca. 30\% IBS (mostly in PI-IBS) } \\
{[23]}\end{array}$ & $\begin{array}{l}\text { Serum TNF- } \alpha \text {, IL-1 } \beta, \text { IL- } 6 \uparrow \\
\text { especially in D-IBS [19] } \\
\text { LPS-induced TNF- } \alpha \text { production } \\
\text { by PBMCs } \uparrow \text { associated with } \\
\text { anxiety [19] }\end{array}$ \\
\hline $\begin{array}{l}\text { Alcoholic liver } \\
\text { disease }\end{array}$ & $\begin{array}{l}\mathrm{IP} \uparrow\left({ }^{51} \mathrm{Cr}-\mathrm{EDT} \text { T test }\right)[25] \\
\text { Increased IP was associated } \\
\text { with dysbiosis }\left({ }^{51} \mathrm{Cr} \text {-EDTA }\right. \\
\text { test })[27] \\
\mathrm{IP} \uparrow \uparrow(\mathrm{L} / \mathrm{M} \text { test) }[26]\end{array}$ & $\begin{array}{l}\text { ZO- } 1 \text { and occludin in the } \\
\text { duodenum } \downarrow[32]\end{array}$ & $\begin{array}{l}\text { Endotoxemia (+) correlated } \\
\text { with ID (PEG Mr } 4000 \text { method) } \\
\text { [29] }\end{array}$ & $\begin{array}{l}\text { Serum IL-8 } 1 \text {, granulocytosis } \\
\text { correlated with endotoxemia in } \\
\text { alcoholic hepatitis [37] } \\
\text { Plasma TNF- } \alpha \uparrow \text { correlated with } \\
\text { endotoxemia in alcoholic cirrhosis } \\
\text { [38] }\end{array}$ \\
\hline$\overline{\text { NAFLD }}$ & $\begin{array}{l}\text { IP } \uparrow\left({ }^{51} \text { Cr-EDTA test) }[44]\right. \\
\text { IP } \uparrow(\mathrm{L} / \mathrm{M} \text { test }) \text { in child } \\
\text { steatohepatitis correlated with } \\
\text { the severity of steatohepatitis } \\
{[45]}\end{array}$ & $\begin{array}{l}\text { ZO- } 1 \text { in the villi } \downarrow \\
\text { Nuclear ZO- } 1 \text { in the crypt } \\
\text { cell } \downarrow \text { correlated with IP } \\
{[44]}\end{array}$ & $\begin{array}{l}\text { Endotoxemia (+) related with } \\
\text { SIBO [47] }\end{array}$ & $\begin{array}{l}\text { Liver TLR4 protein expression } \uparrow \\
\text { in NASH [23] } \\
\text { Liver TLR4 mRNA and serum } \\
\text { TNF- } \alpha \uparrow \text { in NAFLD [47] } \\
\text { Liver TLR4 mRNA } \uparrow(\mathrm{NASH}> \\
\text { NAFL) [48] }\end{array}$ \\
\hline Liver cirrhosis & $\begin{array}{l}\text { IP } \uparrow\left(\mathrm{L} / \mathrm{M} \text { test, }{ }^{51} \mathrm{Cr} \text {-EDTA test, }\right. \\
\text { PEG test) }[54]\end{array}$ & $\begin{array}{l}\text { Occludin and claudin- } 1 \downarrow \\
\text { in the duodenum } \\
\text { negatively correlated with } \\
\text { serum endotoxin levels } \\
\text { [55] }\end{array}$ & $\begin{array}{l}\text { Endotoxemia (+) related with } \\
\text { Child-Pugh grades, renal } \\
\text { disturbance, GI bleeding, and } \\
\text { infection [28] }\end{array}$ & $\begin{array}{l}\text { TNF, IL-2, IL-4, IL-6, IL-8 and } \\
\text { IFN- } \gamma \uparrow \text { especially in those with } \\
\text { massive ascites [59] }\end{array}$ \\
\hline$\overline{\mathrm{PBC}}$ & IP $\uparrow(\mathrm{L} / \mathrm{M}$ test) [63] & IgA secretion $\downarrow[64]$ & $\begin{array}{l}\text { Endotoxemia }(+)[65] \\
\text { IgM antibodies against LTA }(+) \\
{[67]}\end{array}$ & $\begin{array}{l}\text { Liver TLR4 and CD14 protein } \uparrow \\
\text { [65] }\end{array}$ \\
\hline $\begin{array}{l}\text { Obstructive } \\
\text { jaundice }\end{array}$ & $\begin{array}{l}\text { IP } \uparrow(\text { L/M test) }[69] \\
\text { IP } \uparrow(\text { PEG test) }[70]\end{array}$ & $\begin{array}{l}\text { Occludin, claudin }-1,-7 \\
\text { proteins } \downarrow \text { in the } \\
\text { duodenum [75] }\end{array}$ & Endotoxemia (+) [73] & TNF, IL-6, IL-81 [72] \\
\hline$\overline{\text { SAP }}$ & 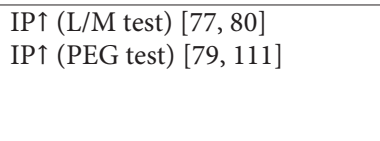 & $\begin{array}{l}\text { TJPs in the colon } \downarrow \\
\text { occludin and ZO- } 1 \downarrow \text { in } \\
\text { patients with BT[82] }\end{array}$ & $\begin{array}{l}\text { Endotoxemia }(+) \text { correlated } \\
\text { with IP }[77,79]\end{array}$ & $\begin{array}{l}\text { Inflammatory cytokines } \uparrow[81] \\
\text { Serum IL-6, TNF- } \alpha \text {, CRP, CT } \\
\text { severity index correlated with IP } \\
{[80]}\end{array}$ \\
\hline
\end{tabular}

IP = Intestinal permeability; sCD14 = soluble CD14; CT = computed tomography.

ithelial changes, circulating microbial products and inflammatory changes of the target organs in various diseases is summarized in table 1.

\section{Inflammatory Bowel Diseases}

A critical etiological factor in IBD is that the mucus layer becomes more permeable to bacteria and bacterial products [2]. Patients with Crohn's disease (CD) exhibit marked increases in intestinal permeability assessed by the lactulose-mannitol (L/M) test [4]. Paracellular intestinal permeability estimated by the Ussing chamber method was increased even in patients with inactive IBD [5], although the maximum blood lactulose concentrations were higher in patients with active diseases [6]. A significant correlation was noted between the maximum blood lactulose concentrations and serum CRP levels [6]. Increased intestinal permeability was also detected in patients with ulcerative colitis (UC) in remission [7]. Intestinal permeability estimated by the serum level of iohexol, a radiographic contrast media, was increased in $50 \%$ of 
CD and in $31 \%$ of UC patients, and was also related to the disease activity judged by the endoscopy [8]. Disrupted barrier function comprises alterations in epithelial TJ, i.e. a reduced number of horizontal $\mathrm{TJ}$ strands and an altered TJ protein (TJP) expression, and subcellular distribution with decreased expression of cellular prion protein in colonic epithelia of CD and UC patients [2,9]. These barrier defects are attributed to the enhanced activity of proinflammatory cytokines like TNF- $\alpha$, INF- $\gamma$, IL- $1 \beta$ and IL13 , which are highly expressed in the chronically inflamed intestine [2].

Systemic endotoxemia was reported to be present in $28 \sim 88 \%$ of patients with UC and $48 \sim 94 \%$ with CD during clinical relapse $[10,11]$. Endotoxemia, its correlation with disease activity, disease extent, and circulating TNF support a pathogenic role of endotoxin in IBD [10]. Serum endotoxin, lipopolysaccharide (LPS)-binding protein (LBP), and soluble CD14 levels were correlated with disease activity and paralleled to a rise in proinflammatory cytokines, suggesting a contribution of bacterial products to the inflammatory cascade in IBD patients [11].

As for the changes in the gut microbiome, a decreased abundance of butyrate-producing Faecalibacterium prausnitzii (Firmicutes phylum, Clostridiales order) may lead butyrate deficiency and intestinal inflammation in IBD [12]. Moreover, an increase in the number of sulfatereducing bacteria, which produce toxic hydrogen sulfide, may provoke epithelial cell injury and inflammation in UC [13]. Metabolome analysis further suggests that bile acid dysregulation due to gut dysbiosis may result in increased intestinal permeability and inflammation in patients with IBD [14].

\section{Irritable Bowel Syndrome}

Increased small bowel and colonic permeability has been noted in both adult and pediatric patients, primarily with postinfectious IBS (PI-IBS) and diarrhea predominant IBS (D-IBS) [15]. The L/M ratio is significantly correlated with IBS interference with activities and work, anxiety, and depression [16]. Increased paracellular permeability was associated with the expression and distribution of TJPs, lower levels of the protein zonula occludens (ZO)-1 and occludin in intestinal tissue [17, $18]$.

Concerning inflammatory changes, Liebregts et al. [19] studied the cytokine production in peripheral blood mononuclear cells (PBMCs) and reported that IBS, espe- cially D-IBS patients, showed high baseline serum TNF- $\alpha$, IL-1 $\beta$, and IL-6 levels. PBMCs in patients with D-IBS further showed enhanced TNF- $\alpha$ release by endotoxin (LPS) stimulation, which was correlated with anxiety [19]. Mast cells, which increase in the colon of IBS patients [20], degranulate to release inflammatory and immune mediators promoting the recruitment of other inflammatory cells [21].

Expression of Toll-like receptor 4 (TLR4; recognizes bacterial LPS) and TLR5 (recognizes flagellin, a common bacterial antigen) is increased in colons of IBS patients compared with controls [22]. Antiflagellin antibodies were found in almost $30 \%$ of IBS (mostly PI-IBS) patients as opposed to only $7 \%$ of healthy controls [23], suggesting the importance of the interaction between the intestinal microbiota and the immune system in these IBS patients [22]. Several susceptibility genes for IBS involved in the innate immunity, recognition of bacteria, or maintenance of intestinal barrier integrity have been identified [24].

\section{Alcoholic Liver Disease}

Noncirrhotic alcoholic patients abstaining from alcohol for less than 4 days almost invariably showed increased intestinal permeability by way of a ${ }^{51} \mathrm{Cr}$-EDTA absorption test [25]. In many patients this abnormality persisted for up to 2 weeks after cessation of drinking [25]. Alcoholics with chronic liver disease showed a markedly increased intestinal permeability by the L/M test, whereas the increase in intestinal permeability was slight in alcoholics with no liver disease [26]. Only patients with increased intestinal permeability had an altered fecal microbiota composition: a drastic decrease in the abundance of Ruminococcus, Faecalibacterium, Subdoligranulum, Oscillibacter, and Anaerofilum belonging to the Ruminococcaceae family [27]. The total amount of bacteria and those belonging to the Ruminococcaceae family, especially for Faecalibacterium prausnitzii was negatively correlated with intestinal permeability, while the genera Dorea and Blautia were positively correlated with intestinal permeability [27].

The passage of viable bacteria from the intestinal lumen through the mesenteric lymph nodes and other sites are defined as bacterial translocation (BT). The concept of BT was later broadened to microbial products or their fragments, such as endotoxin, peptidoglycan, lipopeptides, and bacterial DNA [28]. The liver receives portal blood containing these microbial products and acts as the 
initial site of their filtration and detoxication [28]. Parlesak et al. [29] found a significant correlation between the plasma endotoxin concentrations and the intestinal permeability of polyethylene glycol (PEG) Mr 4000. They discussed PEG as an appropriate probe for the assessment of gut-derived endotoxin translocation on the basis of its homogeneous chemical properties, appropriately adaptable molecular mass and linear, chain-like shape mimicking the structure of endotoxin [29]. Alcohol is known to disrupt gastrointestinal epithelial barrier integrity [30], resulting in the translocation of potentially harmful bacteria and their products such as endotoxins [31, 32]. Alcohol and its metabolites, acetaldehyde and fatty acid ethyl esters, may contribute to the disruption of TJs, mainly through nitric oxide-mediated oxidative tissue damage and alterations in the cytoskeleton, but also through direct cell damage [33-35].

There is strong evidence to support the concept that gut-derived endotoxin as a marker of BT plays a central role in the initiation and progression of alcohol-induced liver injury [36]. Once endotoxin reaches various organs, it powerfully stimulates TLR4 both in hepatic macrophages (Kupffer cells - KCs) and extrahepatic macrophages, which activate downstream signaling pathways responsible for overproduction of proinflammatory cytokines such as TNF- $\alpha$, IL-6, and IL-8. Plasma endotoxin levels were increased with the progression of alcoholic liver injury and reached the maximal level in patients with alcoholic cirrhosis and severe alcoholic hepatitis who showed marked hypercytokinemia [37]. In these patients, plasma endotoxin levels were positively correlated with serum IL-8 levels and peripheral neutrophil counts [37]. In another study on alcoholic cirrhosis, plasma endotoxin levels were strongly correlated with the plasma levels of TNF- $\alpha$ and its receptors -p55 and -p75 [38]. Alcohol induces the LBP and TLR4, and increases responsiveness to gut-derived endotoxin. The binding of LPS to CD14/ TLR4 on KCs stimulates the production of cytokines and oxidants, which leads to hepatic stellate cell activation and collagen synthesis in the liver of patients with alcoholic steatohepatitis $[28,39]$.

Lower median abundances of Bacteroidetes and higher ones of Proteobacteria in the colonic microbiome were proved to be correlated with high levels of serum endotoxin in alcoholics [40]. Endotoxemia and hepatic inflammation are considered as consequences of the expansion of the Gram-negative bacteria from the Proteobacteria phylum, which occur in response to chronic ethanol consumption [41]. A decrease in commensal probiotics could contribute to the loss of protective TJ barrier [42].

\section{Nonalcoholic Fatty Liver Diseases}

Nonalcoholic fatty liver disease (NAFLD) is the hepatic manifestation of the metabolic syndrome. It includes a spectrum of pathological changes ranging from the simple accumulation of fat (NAFL) in the liver through nonalcoholic steatohepatitis (NASH) to fibrosis and cirrhosis [43]. NAFLD patients present increased gut permeability characterized by disruption of the intercellular TJs with decreased TJP ZO-1 expression, which is likely to allow translocations of bacteria and their products [44]. Intestinal permeability is increased in children with NAFLD, and correlates with the severity of steatohepatitis [45]. On the other hand, NASH patients were found to have endotoxemia and overexpression of TLR4 protein in the liver $[46,47]$ associated with proinflammatory cytokine release and systemic inflammation. Hepatic TLR4 mRNA expression and plasma endotoxin levels were proved to be increased in NASH patients compared with NAFL patients [48]. Induction of an intestinal inflammation by dextran sulfate sodium in experimental NASH promotes LPS translocation, hepatic inflammation, and fibrogenesis [49]. Our group reported enhanced $\alpha$-SMA expression (suggesting hepatic stellate cell activation), elevated liver LBP mRNA levels, increased intestinal permeability, and decreased intestinal TJP expression in the rat NASH model fed a choline-deficient L-amino-aciddefined diet [50]. We also proved that oral administration of poorly absorbable antibiotics improved all of these intestinal and liver events and inhibited the progression of liver fibrosis [50].

Small intestinal bacterial overgrowth (SIBO) relevant in NASH patients is also associated with enhanced hepatic expression of TLR4 and release of IL-8 [51]. In the experimental condition of high-fat diet, not only bacterial products but also complete living bacteria can be translocated from the intestinal lumen towards adipose tissues [52]. Adipose tissues in NASH patients are infiltrated by a large number of macrophages, and this recruitment is linked to systemic inflammation and insulin resistance [53].

\section{Liver Cirrhosis}

Many authors have reported that patients with liver cirrhosis revealed intestinal hyperpermeability [54]. Structural and functional changes in the intestinal mucosa that increase intestinal permeability have been regarded as an important pathogenetic factor for several 
complications of liver cirrhosis including bacterial infections. Reduced expression of duodenal occludin and claudin-1 has been found especially in patients with decompensated cirrhosis. Negative correlation was proved between these expressions and serum endotoxin levels [55]. Bacterial products, such as endotoxin, or bacterial DNA can translocate to extraintestinal sites and promote an immunological response similar to that produced by viable bacteria. Pathological BT is a contributing factor in the development of infections and other complications in cirrhosis, by exerting a profound inflammatory state and exacerbating the hemodynamic derangement [54, 56]. SIBO in cirrhosis showed a high correlation with the presence of bacterial DNA fragments in peripheral blood, suggesting that SIBO could be a major risk factor for BT, especially in ascitic patients [57].

Endotoxin binds to TLR4 with the co-receptors CD14 and MD-2. TLR2 heterodimerizes with TLR1 or TLR6 to recognize lipoprotein and peptidoglycan derived from Gram-positive bacteria. Bacterial flagellin is recognized by TLR5. Intracellular TLR3 and TLR9 are activated by microbe-derived nucleic acids including double-stranded RNA and CpG motif containing unmethylated DNA, respectively $[43,58]$. Translocated microbial products thus activate KCs through TLRs, which activate innate immune responses including cytokine production [39]. The circulating levels of inflammatory cytokines TNF, IL2 , IL-4, IL-6, IL-8, and IFN- $\gamma$ were especially high in cirrhotic patients with massive ascites [59]. Depressed elimination of endotoxin by KCs causes spillover endotoxemia. Decreased endotoxin inactivation in the blood is considered to enhance the processing of endotoxin by extrahepatic macrophages which secrete larger amounts of TNF than KCs $[28,60,61]$. The excessive cytokine response to endotoxin by splenic and pulmonary alveolar macrophages may be important in the pathogenesis of acute respiratory distress syndrome and multiple organ failure in advanced liver cirrhosis [28, 61]. Hepatic encephalopathy is also closely related to inflammatory reaction attributable to leaky gut and endotoxemia [28].

\section{Primary Biliary Cholangitis}

$\mathrm{PBC}$ is a chronic inflammatory cholestatic disease of unknown etiology that affects small and medium intrahepatic bile ducts [62]. The permeability of both the stomach and small intestine was increased in patients with $\mathrm{PBC}$ estimated by the sugar test and the $\mathrm{L} / \mathrm{M}$ test [63]. The majority $(66.6 \%)$ of patients with abnormal permeability did not have evidence of portal hypertension, and some patients with very early-stage PBC had increased permeability [63]. So far, no structural changes in the intestinal mucosa have been reported, although an IgA secretion defect in the intestinal epithelium was proposed [64]. Significant endotoxemia was found in patients with early $\mathrm{PBC}$, and enhanced immunohistochemical expression of TLR4 and CD14 was found in the liver tissues of PBC patients [65]. TLR4 expression is significantly elevated in biliary epithelial cells and periportal hepatocytes of PBC patients [66]. PBC sera were also positive for IgM antibodies against lipoteichoic acid (LTA), the Gram-positive bacterial cell wall component [67]. LTA was localized around the sites of chronic nonsuppurative destructive cholangitis in the portal area in stage 1-2 PBC and was detected around the sites of ductular proliferation at the periphery of portal tracts in stage 3-4 PBC [67].

\section{Obstructive Jaundice}

Surgery for relief of obstructive jaundice has a risk of sepsis and renal dysfunction [68]. Increased intestinal permeability was confirmed in these patients both by the L/M test [69] and the polyethylene glycol test [70], which may be related to frequently observed BT [71]. Malignant obstructive jaundice caused increased blood concentrations of endotoxin and inflammatory cytokines [72, 73]. Portal endotoxemia resulted in an increase in TNF- $\alpha$, IL6 , and IL-10 in the bile duct-ligated rats [74]. Altered TJPs, decreased expression of occludin, claudin- 1 , and -7 , were found in the duodenal epithelium of patients with obstructive jaundice [75]. Bile duct ligation in animals also resulted in the regional loss of occludin expression in the intestinal epithelium, which was improved by bile feeding [76]. Bile acids inhibit the growth of Bacteroides, Clostridia, Lactobacillus and Streptococcus, and the absence of bile acids results in a disturbed intestinal bacterial balance with overgrowth of Gram-negative bacteria [68].

\section{Acute Pancreatitis}

Increased intestinal permeability was confirmed by several methods in patients with acute pancreatitis [7780]. The intestinal permeability was correlated with plasma endotoxin $[77,79,80]$, serum TNF- $\alpha[77,80]$, IL-6, $\mathrm{CRP}$, and the severity index estimated by computed tomography [80]. The urinary concentration of intestinal 
fatty acid-binding protein, a sensitive marker of intestinal ischemia, correlated positively with intestinal permeability, which suggests that splanchnic hypoperfusion induces the loss of intestinal mucosal integrity [78]. Overwhelming systemic production of inflammatory mediators and early organ failure are characteristics of SAP [81]. The expression of TJPs in the colonic mucosal tissue was decreased in patients with SAP, $62 \%$ of which showed BT (positive bacterial DNA in the peripheral blood) [82]. Further, patients with BT showed a lower level of occludin and ZO-1 expression [82]. The failure of intestinal barrier is associated with translocation of bacteria and inflammatory products through the intestinal wall, which can be responsible for the infection of the necrotic pancreas and systemic inflammatory response [83]. Higher rates of multiple organ failure and infectious complications were observed in patients with SAP and intestinal dysbiosis: the increase in Enterococcus and decrease in $\mathrm{Bi}$ fidobacterium [84]. Serum IL-6 levels were positively correlated with the abundance of Enterobacteriaceae and Enterococcus and negatively correlated with that of Bifidobacterium, whereas plasma endotoxin was positively correlated with the abundance of Enterococcus, which suggests that the intestinal dysbiosis may be involved in the progression of acute pancreatitis [84].

\section{Chronic Kidney Disease}

Increased intestinal permeability in patients with chronic kidney disease (CKD) was reported in the early 1990s [85] after the studies on the intestinal mucosal changes showing shortening of the villi, elongation of the crypts, and infiltration of lamina propria [86, 87]. An in vitro study using TJ-forming human enterocytes revealed that exposure to plasma from patients with end-stage renal disease damages the epithelial TJ and impairs its barrier function [88]. Uremia-induced disruption of intestinal TJ and barrier function is, in part, mediated by urea [89]. This leaky barrier allows the translocation of endotoxin, bacterial DNA, and uremic toxins from the gut [90]. Bacterial DNA from the colon was detected in the mesenteric lymph nodes, liver, spleen, and blood of CKD rats [91]. Circulating endotoxin levels, which increase along the stages of CKD and are highest in patients on hemodialysis or peritoneal dialysis $[92,93]$, are correlated with serum CRP levels [92-94]. The gut microbiota in patients with end-stage renal disease exhibited significant expansion of bacterial families possessing urease, uricase and indole, and p-cresol-forming enzymes, and contrac-

Increased Intestinal Permeability and the Risk of Inflammation tion of families possessing butyrate-forming enzymes [95]. Given the deleterious effects of indoxyl sulfate, pcresol sulfate, and urea-derived ammonia, and beneficial actions of short chain fatty acid (SCFA) butyrate, these changes in intestinal microbial metabolism may contribute to uremic toxicity and inflammation [95].

\section{Chronic Heart Failure}

Patients with chronic heart failure (CHF) showed a $35 \%$ increase in small intestinal permeability by the L/M test and a $210 \%$ increase in large intestinal permeability by the sucralose test [96]. Increased wall thickness of both small and large intestines and larger amounts of adherent bacteria within mucus were also noted in CHF patients [96]. Increased intestinal permeability was associated with clinical disease severity, venous blood congestion, and serum CRP [97]. Raised plasma endotoxin and cytokine levels were found in patients with $\mathrm{CHF}$ during acute edematous exacerbation [98]. Adults with congenital heart disease had elevated levels of inflammatory cytokines and endotoxin, which were related to the functional status [99]. It was also reported that CHF patients with abnormal endotoxin levels had higher concentrations of TNF and sTNF-R1 [100]. The above results all indicate that disturbed intestinal microcirculation and barrier function in CHF seem to induce translocations of bacteria and their products and to trigger cytokine generation, thereby contributing to impaired cardiac function [101]. An analysis of gut microbiota in CHF patients revealed that they had massive quantities of pathogenic bacteria such as Campylobacter, Shigella, Salmonella, Yersinia enterocolitica, and Candida species compared with normal controls, which may be related to increased intestinal permeability, and have intestinal overgrowth of pathogenic bacteria and clinical disease severity [97].

\section{Depression}

There is now full evidence that major depression is accompanied by an activation of the inflammatory response system and that proinflammatory cytokines and endotoxin may induce depressive symptoms [102]. The prevalence and median values of serum IgM and IgA against the LPS of Gram-negative enterobacteria, i.e. Hafnia alvei, Pseudomonas aeruginosa, Morganella morganii, Pseudomonas putida, Citrobacter koseri, and Klebsiella pneumoniae were significantly higher in depressed patients 
than in controls [103]. Deranged intestinal permeability may underpin the chronic low-grade inflammation observed in depression, and the gut microbiome plays a critical role in regulating intestinal permeability [1]. Bacterial DNA is present in whole serum from depressed patients who also display increased TLR4 expression on PBMC [1]. Patients with major depression exhibit inflammatory responses, including increased expression of proinflammatory cytokines and their receptors and increased levels of acute-phase reactants, chemokines, and soluble adhesion molecules in peripheral blood and cerebrospinal fluid [104]. Peripheral blood gene expression profiles revealed an overexpression of proinflammatory IL-6, IL-8, and type I IFN-induced signaling pathways [104-107]. Further, increased expression of a variety of innate immune genes and proteins, including IL- $1 \beta$, IL-6, TNF- $\alpha$, TLR3, and TLR4, has been found in postmortem brain samples from suicide victims that had depression $[108,109]$.

\section{Conclusions}

We have presented here the clinical and experimental evidence in several diseases in which increased intestinal permeability owing to gut barrier dysfunction may be responsible for inflammatory changes, although we are not convinced that it really influences the risk of inflammation. Direct cause-and-effect relationships have not been demonstrated anywhere. There has been no study to compare the grade of inflammation between those with and without increased intestinal permeability. No experimental study has been directed to confirm this hypothesis. Nevertheless, when we have collected references using the keywords 'intestinal permeability', 'gut barrier', 'dysbiosis', 'endotoxin', 'bacterial translocation', 'Tolllike receptor', 'cytokine' and so on, a common story consistent with the thesis has surprisingly appeared concerning diseases all over the body. Although there still remain lot of issues to be confirmed concerning the results and interpretations, this 'leaky gut hypothesis' seems to be a reasonable explanation of the pathophysiological background of these diseases. The hypothesis contains broad and deep clinical implications and suggests the importance of the intestine in human health and disease. The whole story on 'leaky gut' in the diversity of human diseases could not be covered in this short review, but may be presented in an entire book.

Recently, a marked technological progress in the studies of gut microbiota has opened a new research field. Ac- cumulating lines of evidence support the close relationship of gut microbiota and intestinal functions [43]. The 'leaky gut hypothesis' may be coupled with the 'dysbiosis hypothesis' when the host reactions to gut dysbiosis are more clearly defined in association with intestinal changes. It is true that intestinal permeability is a new target for disease prevention and therapy [2]. Although probiotics, prebiotics, antibiotics and their combinations have been extensively tried until now, safe and useful medication to repair 'leaky gut' is still difficult to produce. Anyway, it should be noted that food intake affects the intestinal microbiome composition and intestinal permeability [2]. Remarkable increases in IBD patients and diabetic patients over the past 30 years in Japan may be related to the dramatic changes in the environment, especially the changes in dietary habits: from the traditional Japanese foods to high-fat, high-calorie Western foods [110]. The meaningful advice by a Japanese clinician in 1970s with a word of 'Ishoku-Dogen', which proposes a restricted balanced diet for prevention and treatment of illness, is expected to improve the situation. Further investigations on the relationship of diet to gut microbiome and intestinal functions may support that an ideal traditional diet from the old East may help the 'leaky gut syndrome' of modern people in the West and East. There is a great possibility that meticulous management of gut microbiota and intestinal functions improve general human health by virtue of lifestyle improvement combined with dietary and pharmaceutical approaches.

\section{Disclosure Statement}

I have no conflicts of interest to declare that are relevant to the subject of this review paper and any of the statements in it.

\footnotetext{
References $>_{1}$ Kelly JR, Kennedy PJ, Cryan JF, Dinan TG, Clarke G, Hyland NP: Breaking down the barriers: the gut microbiome, intestinal permeability and stress-related psychiatric disorders. Front Cell Neurosci 2015;9:392.

-2 Bischoff SC, Barbara G, Buurman W, Ockhuizen T, Schulzke JD, Serino M, Tilg H, Watson A, Wells JM: Intestinal permeability - a new target for disease prevention and therapy. BMC Gastroenterol 2014; 14:189.

-3 Valentini L, Ramminger S, Haas V, Postrach E, Werich M, Fischer A, Koller M, Swidsinski A, Bereswill S, Lochs H, Schulzke JD: Small intestinal permeability in older adults. Physiol Rep 2014;2:e00281.
} 
-4 Wyatt J, Oberhuber G, Pongratz S, Puspok A, 15 Camilleri M, Lasch K, Zhou W: Irritable bowMoser G, Novacek G, Lochs H, Vogelsang H: Increased gastric and intestinal permeability in patients with Crohn's disease. Am J Gastroenterol 1997;92:1891-1896.

5 Vivinus-Nebot M, Frin-Mathy G, Bzioueche H, Dainese R, Bernard G, Anty R, Filippi J, Saint-Paul MC, Tulic MK, Verhasselt V, Hebuterne X, Piche T: Functional bowel symptoms in quiescent inflammatory bowel diseases: role of epithelial barrier disruption and low-grade inflammation. Gut 2014;63:744752.

6 Oriishi T, Sata M, Toyonaga A, Sasaki E, Tanikawa K: Evaluation of intestinal permeability in patients with inflammatory bowel disease using lactulose and measuring antibodies to lipid A. Gut 1995;36:891-896.

7 Buning C, Geissler N, Prager M, Sturm A, Baumgart DC, Buttner J, Buhner S, Haas V, Lochs $\mathrm{H}$ : Increased small intestinal permeability in ulcerative colitis: rather genetic than environmental and a risk factor for extensive disease? Inflamm Bowel Dis 2012;18:19321939.

8 Gerova VA, Stoynov SG, Katsarov DS, Svinarov DA: Increased intestinal permeability in inflammatory bowel diseases assessed by iohexol test. World J Gastroenterol 2011;17: 2211-2215.

9 Petit CS, Barreau F, Besnier L, Gandille P, Riveau B, Chateau D, Roy M, Berrebi D, Svrcek M, Cardot P, Rousset M, Clair C, Thenet S: Requirement of cellular prion protein for intestinal barrier function and mislocalization in patients with inflammatory bowel disease. Gastroenterology 2012;143:122132.e15.

10 Gardiner KR, Halliday MI, Barclay GR, Milne L, Brown D, Stephens S, Maxwell RJ, Rowlands BJ: Significance of systemic endotoxaemia in inflammatory bowel disease. Gut 1995; 36:897-901.

11 Pastor Rojo O, Lopez San Roman A, Albeniz Arbizu E, de la Hera Martinez A, Ripoll Sevillano E, Albillos Martinez A: Serum lipopolysaccharide-binding protein in endotoxemic patients with inflammatory bowel disease. Inflamm Bowel Dis 2007;13:269-277.

12 Takaishi H, Matsuki T, Nakazawa A, Takada T, Kado S, Asahara T, Kamada N, Sakuraba A, Yajima T, Higuchi H, Inoue N, Ogata H, Iwao Y, Nomoto K, Tanaka R, Hibi T: Imbalance in intestinal microflora constitution could be involved in the pathogenesis of inflammatory bowel disease. Int J Med Microbiol 2008;298: 463-472.

13 Pitcher MC, Beatty ER, Cummings JH: The contribution of sulphate reducing bacteria and 5-aminosalicylic acid to faecal sulphide in patients with ulcerative colitis. Gut 2000;46: 64-72.

14 Baars A, Oosting A, Knol J, Garssen J, van Bergenhenegouwen J: The gut microbiota as a therapeutic target in ibd and metabolic disease: a role for the bile acid receptors FXR and TGR5. Microorganisms 2015;3:641-666. el syndrome: methods, mechanisms, and pathophysiology. The confluence of increased permeability, inflammation, and pain in irritable bowel syndrome. Am J Physiol Gastrointest Liver Physiol 2012;303:G775-G785.

16 Shulman RJ, Jarrett ME, Cain KC, Broussard EK, Heitkemper MM: Associations among gut permeability, inflammatory markers, and symptoms in patients with irritable bowel syndrome. J Gastroenterol 2014;49:14671476.

17 Piche T, Barbara G, Aubert P, Bruley des Varannes S, Dainese R, Nano JL, Cremon C, Stanghellini V, De Giorgio R, Galmiche JP, Neunlist M: Impaired intestinal barrier integrity in the colon of patients with irritable bowel syndrome: involvement of soluble mediators. Gut 2009;58:196-201.

18 Bertiaux-Vandaele N, Youmba SB, Belmonte L, Lecleire S, Antonietti M, Gourcerol G, Leroi AM, Dechelotte P, Menard JF, Ducrotte P, Coeffier M: The expression and the cellular distribution of the tight junction proteins are altered in irritable bowel syndrome patients with differences according to the disease subtype. Am J Gastroenterol 2011;106:21652173.

19 Liebregts T, Adam B, Bredack C, Roth A, Heinzel S, Lester S, Downie-Doyle S, Smith E, Drew P, Talley NJ, Holtmann G: Immune activation in patients with irritable bowel syndrome. Gastroenterology 2007;132:913920.

20 Sinagra E, Pompei G, Tomasello G, Cappello F, Morreale GC, Amvrosiadis G, Rossi F, Lo Monte AI, Rizzo AG, Raimondo D: Inflammation in irritable bowel syndrome: myth or new treatment target? World J Gastroenterol 2016;22:2242-2255.

21 Lee YJ, Park KS: Irritable bowel syndrome emerging paradigm in pathophysiology. World J Gastroenterol 2014;20:2456-2469.

22 Ringel Y, Maharshak N: Intestinal microbiota and immune function in the pathogenesis of irritable bowel syndrome. Am J Physiol Gastrointest Liver Physiol 2013;305:G529G541.

23 Schoepfer AM, Schaffer T, Seibold-Schmid B, Muller S, Seibold F: Antibodies to flagellin indicate reactivity to bacterial antigens in IBS patients. Neurogastroenterol Motil 2008;20: 1110-1118.

24 Ohman L, Simren M: Intestinal microbiota and its role in irritable bowel syndrome (IBS). Curr Gastroenterol Rep 2013;15:323.

25 Bjarnason I, Peters TJ, Wise RJ: The leaky gut of alcoholism: possible route of entry for toxic compounds. Lancet 1984;1:179-182.

26 Keshavarzian A, Holmes EW, Patel M, Iber F, Fields JZ, Pethkar S: Leaky gut in alcoholic cirrhosis: a possible mechanism for alcoholinduced liver damage. Am J Gastroenterol 1999;94:200-207.

27 Leclercq S, Matamoros S, Cani PD, Neyrinck AM, Jamar F, Starkel P, Windey K, Tremaroli V, Backhed F, Verbeke K, de Timary P, Del- zenne NM: Intestinal permeability, gut-bacterial dysbiosis, and behavioral markers of alcohol-dependence severity. Proc Natl Acad Sci USA 2014;111:E4485-E4493.

28 Fukui H: Gut-liver axis in liver cirrhosis: how to manage leaky gut and endotoxemia. World J Hepatol 2015;7:425-442.

29 Parlesak A, Schafer C, Schutz T, Bode JC, Bode C: Increased intestinal permeability to macromolecules and endotoxemia in patients with chronic alcohol abuse in different stages of alcohol-induced liver disease. J Hepatol 2000;32:742-747.

30 Keshavarzian A, Fields JZ, Vaeth J, Holmes EW: The differing effects of acute and chronic alcohol on gastric and intestinal permeability. Am J Gastroenterol 1994;89:2205-2211.

- 31 Bode JC, Bode C, Heidelbach R, Durr HK, Martini GA: Jejunal microflora in patients with chronic alcohol abuse. Hepatogastroenterology 1984;31:30-34.

- 32 Elamin E, Masclee A, Troost F, Pieters HJ, Keszthelyi D, Aleksa K, Dekker J, Jonkers D: Ethanol impairs intestinal barrier function in humans through mitogen activated protein kinase signaling: a combined in vivo and in vitro approach. PLoS One 2014;9:e107421.

33 Kalaitzakis E: Gastrointestinal dysfunction in liver cirrhosis. World J Gastroenterol 2014; 20:14686-14695.

34 Elamin EE, Masclee AA, Dekker J, Jonkers DM: Ethanol metabolism and its effects on the intestinal epithelial barrier. Nutr Rev 2013;71:483-499.

-35 Tang Y, Forsyth CB, Farhadi A, Rangan J, Jakate S, Shaikh M, Banan A, Fields JZ, Keshavarzian A: Nitric oxide-mediated intestinal injury is required for alcohol-induced gut leakiness and liver damage. Alcohol Clin Exp Res 2009;33:1220-1230.

36 Yan AW, Fouts DE, Brandl J, Starkel P, Torralba M, Schott E, Tsukamoto H, Nelson KE, Brenner DA, Schnabl B: Enteric dysbiosis associated with a mouse model of alcoholic liver disease. Hepatology 2011;53:96-105.

-37 Fujimoto M, Uemura M, Nakatani Y, Tsujita S, Hoppo K, Tamagawa T, Kitano H, Kikukawa M, Ann T, Ishii Y, Kojima H, Sakurai S, Tanaka R, Namisaki T, Noguchi R, Higashino T, Kikuchi E, Nishimura K, Takaya A, Fukui H: Plasma endotoxin and serum cytokine levels in patients with alcoholic hepatitis: relation to severity of liver disturbance. Alcohol Clin Exp Res 2000;24:48S-54S.

38 Hanck C, Rossol S, Bocker U, Tokus M, Singer MV: Presence of plasma endotoxin is correlated with tumour necrosis factor receptor levels and disease activity in alcoholic cirrhosis. Alcohol Alcohol 1998;33:606-608.

39 Guo J, Friedman SL: Toll-like receptor 4 signaling in liver injury and hepatic fibrogenesis. Fibrogenesis Tissue Repair 2010;3:21.

40 Mutlu EA, Gillevet PM, Rangwala H, Sikaroodi M, Naqvi A, Engen PA, Kwasny M, Lau $\mathrm{CK}$, Keshavarzian A: Colonic microbiome is altered in alcoholism. Am J Physiol Gastrointest Liver Physiol 2012;302:G966-G978. 
41 Bull-Otterson L, Feng W, Kirpich I, Wang Y, 52 Amar J, Chabo C, Waget A, Klopp P, Vachoux Qin X, Liu Y, Gobejishvili L, Joshi-Barve S, Ayvaz T, Petrosino J, Kong M, Barker D, McClain C, Barve S: Metagenomic analyses of alcohol induced pathogenic alterations in the intestinal microbiome and the effect of Lactobacillus rhamnosus GG treatment. PLoS One 2013;8:e53028.

42 Wang Y, Kirpich I, Liu Y, Ma Z, Barve S, McClain CJ, Feng W: Lactobacillus rhamnosus GG treatment potentiates intestinal hypoxiainducible factor, promotes intestinal integrity and ameliorates alcohol-induced liver injury. Am J Pathol 2011;179:2866-2875.

43 Fukui H: Gut microbiota and host reaction in liver diseases. Microorganisms 2015;3:759791.

-44 Miele L, Valenza V, La Torre G, Montalto M, Cammarota G, Ricci R, Masciana R, Forgione A, Gabrieli ML, Perotti G, Vecchio FM, Rapaccini G, Gasbarrini G, Day CP, Grieco A: Increased intestinal permeability and tight junction alterations in nonalcoholic fatty liver disease. Hepatology 2009;49:1877-1887.

-45 Giorgio V, Miele L, Principessa L, Ferretti F, 56 Villa MP, Negro V, Grieco A, Alisi A, Nobili $\mathrm{V}$ : Intestinal permeability is increased in children with non-alcoholic fatty liver disease, and correlates with liver disease severity. Dig Liver Dis 2014;46:556-560.

-46 Alisi A, Manco M, Devito R, Piemonte F, Nobili V: Endotoxin and plasminogen activator inhibitor-1 serum levels associated with nonalcoholic steatohepatitis in children. J Pediatr Gastroenterol Nutr 2010;50:645-649.

-47 Kapil S, Duseja A, Sharma BK, Singla B, Chakraborti A, Das A, Ray P, Dhiman RK, Chawla Y: Small intestinal bacterial overgrowth and toll like receptor signaling in patients with nonalcoholic fatty liver disease. J Gastroenterol Hepatol 2016;31:213-221.

-48 Sharifnia T, Antoun J, Verriere TG, Suarez G, Wattacheril J, Wilson KT, Peek RM Jr, Abumrad NN, Flynn CR: Hepatic TLR4 signaling in obese NAFLD. Am J Physiol Gastrointest Liver Physiol 2015;309:G270-G278.

49 Gabele E, Dostert K, Hofmann C, Wiest R, Scholmerich J, Hellerbrand C, Obermeier F: DSS induced colitis increases portal LPS levels and enhances hepatic inflammation and fibrogenesis in experimental NASH. J Hepatol 2011;55:1391-1399.

50 Douhara A, Moriya K, Yoshiji H, Noguchi R, Namisaki T, Kitade M, Kaji K, Aihara Y, Nishimura N, Takeda K, Okura Y, Kawaratani H, Fukui H: Reduction of endotoxin attenuates liver fibrosis through suppression of hepatic stellate cell activation and remission of intestinal permeability in a rat non-alcoholic steatohepatitis model. Mol Med Rep 2015;11:1693-1700.

- 51 Shanab AA, Scully P, Crosbie O, Buckley M, O'Mahony L, Shanahan F, Gazareen S, Murphy E, Quigley EM: Small intestinal bacterial overgrowth in nonalcoholic steatohepatitis: association with toll-like receptor 4 expression and plasma levels of interleukin 8. Dig Dis Sci 2011;56:1524-1534.
C, Bermudez-Humaran LG, Smirnova N, Berge M, Sulpice T, Lahtinen S, Ouwehand A, Langella P, Rautonen N, Sansonetti PJ, Burcelin R: Intestinal mucosal adherence and translocation of commensal bacteria at the early onset of type 2 diabetes: molecular mechanisms and probiotic treatment. EMBO Mol Med 2011;3:559-572.

53 Ouchi N, Parker JL, Lugus JJ, Walsh K: Adipokines in inflammation and metabolic disease. Nat Rev Immunol 2011;11:85-97.

54 Pijls KE, Jonkers DM, Elamin EE, Masclee AA, Koek GH: Intestinal epithelial barrier function in liver cirrhosis: an extensive review of the literature. Liver Int 2013;33:1457-1469.

55 Assimakopoulos SF, Tsamandas AC, Tsiaoussis GI, Karatza E, Triantos C, Vagianos CE, Spiliopoulou I, Kaltezioti V, Charonis A, Nikolopoulou VN, Scopa CD, Thomopoulos KC: Altered intestinal tight junctions' expression in patients with liver cirrhosis: a pathogenetic mechanism of intestinal hyperpermeability. Eur J Clin Invest 2012;42:439-446.

56 Bellot P, Frances R, Such J: Pathological bacterial translocation in cirrhosis: pathophysiology, diagnosis and clinical implications. Liver Int 2013;33:31-39.

57 Jun DW, Kim KT, Lee OY, Chae JD, Son BK, Kim SH, Jo YJ, Park YS: Association between small intestinal bacterial overgrowth and peripheral bacterial DNA in cirrhotic patients. Dig Dis Sci 2010;55:1465-1471.

58 Seki E, Schnabl B: Role of innate immunity and the microbiota in liver fibrosis: crosstalk between the liver and gut. J Physiol 2012;590: 447-458.

59 Attar BM, George M, Ion-Nedelcu N, Ramadori G, Thiel DH: Disease dependent qualitative and quantitative differences in the inflammatory response to ascites occurring in cirrhotics. World J Hepatol 2014;6:85-91.

60 Fukui H, Tsujita S, Matsumoto M, Morimura M, Kitano H, Kinoshita K, Kikuchi E, Okamoto Y, Tsujii T: Endotoxin inactivating action of plasma in patients with liver cirrhosis. Liver 1995; 15:104-109.

61 Nakatani Y, Fukui H, Kitano H, Nagamoto I, Tsujimoto T, Kuriyama S, Kikuchi E, Hoppou $\mathrm{K}$, Tsujii T: Endotoxin clearance and its relation to hepatic and renal disturbances in rats with liver cirrhosis. Liver 2001;21:64-70.

62 Soares JB, Pimentel-Nunes P, Roncon-Albuquerque R, Leite-Moreira A: The role of lipopolysaccharide/toll-like receptor 4 signaling in chronic liver diseases. Hepatol Int 2010;4: 659-672.

63 Feld JJ, Meddings J, Heathcote EJ: Abnormal intestinal permeability in primary biliary cirrhosis. Dig Dis Sci 2006;51:1607-1613.

64 Floreani A, Baragiotta A, Pizzuti D, Martines D, Cecchetto A, Chiarelli S: Mucosal IgA defect in primary biliary cirrhosis. Am J Gastroenterol 2002;97:508-510.

65 Zhao J, Zhao S, Zhou G, Liang L, Guo X, Mao P, Zhou X, Wang H, Nan Y, Xu D, Yu J: Altered biliary epithelial cell and monocyte re- sponses to lipopolysaccharide as a TLR ligand in patients with primary biliary cirrhosis. Scand J Gastroenterol 2011;46:485-494.

66 Wang AP, Migita K, Ito M, Takii Y, Daikoku M, Yokoyama T, Komori A, Nakamura M, Yatsuhashi H, Ishibashi H: Hepatic expression of toll-like receptor 4 in primary biliary cirrhosis. J Autoimmun 2005;25:85-91.

-67 Haruta I, Hashimoto E, Kato Y, Kikuchi K, Kato H, Yagi J, Uchiyama T, Kobayash M, Shiratori K: Lipoteichoic acid may affect the pathogenesis of bile duct damage in primary biliary cirrhosis. Autoimmunity 2006;39:129-135.

68 Assimakopoulos SF, Scopa CD, Vagianos CE: Pathophysiology of increased intestinal permeability in obstructive jaundice. World J Gastroenterol 2007;13:6458-6464.

69 Welsh FK, Ramsden CW, MacLennan K, Sheridan MB, Barclay GR, Guillou PJ, Reynolds JV: Increased intestinal permeability and altered mucosal immunity in cholestatic jaundice. Ann Surg 1998;227:205-212.

-70 Parks RW, Clements WD, Smye MG, Pope C, Rowlands BJ, Diamond T: Intestinal barrier dysfunction in clinical and experimental obstructive jaundice and its reversal by internal biliary drainage. Br J Surg 1996;83:13451349.

71 Assimakopoulos SF, Vagianos CE, Charonis A, Nikolopoulou VN, Scopa CD: Intestinal failure in obstructive jaundice. World J Gastroenterol 2005;11:3806-3807.

-72 Kimmings AN, van Deventer SJ, Obertop H, Rauws EA, Huibregtse K, Gouma DJ: Endotoxin, cytokines, and endotoxin binding proteins in obstructive jaundice and after preoperative biliary drainage. Gut 2000;46:725-731.

-73 Ljungdahl M, Osterberg J, Ransjo U, Engstrand L, Haglund U: Inflammatory response in patients with malignant obstructive jaundice. Scand J Gastroenterol 2007;42:94-102.

-74 Badger SA, Jones C, McCaigue M, Clements BW, Parks RW, Diamond T, McCallion K, Taylor MA: Cytokine response to portal endotoxaemia and neutrophil stimulation in obstructive jaundice. Eur J Gastroenterol Hepatol 2012;24:25-32.

75 Assimakopoulos SF, Tsamandas AC, Louvros E, Vagianos CE, Nikolopoulou VN, Thomopoulos KC, Charonis A, Scopa CD: Intestinal epithelial cell proliferation, apoptosis and expression of tight junction proteins in patients with obstructive jaundice. Eur J Clin Invest 2011;41:117-125.

76 Yang R, Harada T, Li J, Uchiyama T, Han Y, Englert JA, Fink MP: Bile modulates intestinal epithelial barrier function via an extracellular signal related kinase $1 / 2$ dependent mechanism. Intensive Care Med 2005;31:709-117.

-77 Liu H, Li W, Wang X, Li J, Yu W: Early gut mucosal dysfunction in patients with acute pancreatitis. Pancreas 2008;36:192-196.

-78 Rahman SH, Ammori BJ, Holmfield J, Larvin $\mathrm{M}$, McMahon MJ: Intestinal hypoperfusion contributes to gut barrier failure in severe acute pancreatitis. J Gastrointest Surg 2003;7: 26-35; discussion 35-36. 
79 Ammori BJ, Leeder PC, King RF, Barclay GR, Martin IG, Larvin M, McMahon MJ: Early increase in intestinal permeability in patients with severe acute pancreatitis: correlation with endotoxemia, organ failure, and mortality. J Gastrointest Surg 1999;3:252-262.

$\checkmark 80$ Koh YY, Jeon WK, Cho YK, Kim HJ, Chung WG, Chon CU, Oh TY, Shin JH: The effect of intestinal permeability and endotoxemia on the prognosis of acute pancreatitis. Gut Liver 2012;6:505-511.

-81 Kylanpaa ML, Repo H, Puolakkainen PA: Inflammation and immunosuppression in severe acute pancreatitis. World J Gastroenterol 2010;16:2867-2872.

82 Deng WS, Zhang J, Ju H, Zheng HM, Wang J, Wang S, Zhang DL: Arpin contributes to bacterial translocation and development of severe acute pancreatitis. World J Gastroenterol 2015;21:4293-4301.

-83 Capurso G, Zerboni G, Signoretti M, Valente R, Stigliano S, Piciucchi M, Delle Fave G: Role of the gut barrier in acute pancreatitis. J Clin Gastroenterol 2012;46(suppl):S46-S51.

-84 Tan C, Ling Z, Huang Y, Cao Y, Liu Q, Cai T, Yuan H, Liu C, Li Y, Xu K: Dysbiosis of intestinal microbiota associated with inflammation involved in the progression of acute pancreatitis. Pancreas 2015;44:868-875.

85 Magnusson M, Magnusson KE, Sundqvist T, Denneberg $\mathrm{T}$ : Impaired intestinal barrier function measured by differently sized polyethylene glycols in patients with chronic renal failure. Gut 1991;32:754-759.

-86 Goldstein DA, Horowitz RE, Petit S, Haldimann B, Massry SG: The duodenal mucosa in patients with renal failure: response to 1,25(OH)2D3. Kidney Int 1981;19:324-331.

$\$ 87$ Vaziri ND, Dure-Smith B, Miller R, Mirahmadi MK: Pathology of gastrointestinal tract in chronic hemodialysis patients: an autopsy study of 78 cases. Am J Gastroenterol 1985;80: 608-611.

-88 Vaziri ND, Goshtasbi N, Yuan J, Jellbauer S, Moradi H, Raffatellu M, Kalantar-Zadeh K: Uremic plasma impairs barrier function and depletes the tight junction protein constituents of intestinal epithelium. Am J Nephrol 2012;36:438-443.

89 Vaziri ND, Yuan J, Norris K: Role of urea in intestinal barrier dysfunction and disruption of epithelial tight junction in chronic kidney disease. Am J Nephrol 2013;37:1-6.

90 Lau WL, Kalantar-Zadeh K, Vaziri ND: The gut as a source of inflammation in chronic kidney disease. Nephron 2015;130:92-98.
91 Wang F, Zhang P, Jiang H, Cheng S: Gut bacterial translocation contributes to microinflammation in experimental uremia. Dig Dis Sci 2012;57:2856-2862.

92 Szeto CC, Kwan BC, Chow KM, Lai KB, Chung KY, Leung CB, Li PK: Endotoxemia is related to systemic inflammation and atherosclerosis in peritoneal dialysis patients. Clin J Am Soc Nephrol 2008;3:431-436.

93 McIntyre CW, Harrison LE, Eldehni MT, Jefferies HJ, Szeto CC, John SG, Sigrist MK, Burton JO, Hothi D, Korsheed S, Owen PJ, Lai KB, Li PK: Circulating endotoxemia: a novel factor in systemic inflammation and cardiovascular disease in chronic kidney disease. Clin J Am Soc Nephrol 2011;6:133-141.

-94 Feroze U, Kalantar-Zadeh K, Sterling KA, Molnar MZ, Noori N, Benner D, Shah V, Dwivedi R, Becker K, Kovesdy CP, Raj DS: Examining associations of circulating endotoxin with nutritional status, inflammation, and mortality in hemodialysis patients. J Ren Nutr 2012;22:317-326.

95 Wong J, Piceno YM, Desantis TZ, Pahl M, Andersen GL, Vaziri ND: Expansion of urease- and uricase-containing, indole- and pcresol-forming and contraction of shortchain fatty acid-producing intestinal microbiota in ESRD. Am J Nephrol 2014;39: 230-237.

96 Sandek A, Bauditz J, Swidsinski A, Buhner S, Weber-Eibel J, von Haehling S, Schroedl W, Karhausen T, Doehner W, Rauchhaus M, Poole-Wilson P, Volk HD, Lochs H, Anker SD: Altered intestinal function in patients with chronic heart failure. J Am Coll Cardiol 2007;50:1561-1569.

97 Pasini E, Aquilani R, Testa C, Baiardi P, Angioletti S, Boschi F, Verri M, Dioguardi F: Pathogenic gut flora in patients with chronic heart failure. JACC Heart Fail 2015;4:220227.

98 Niebauer J, Volk HD, Kemp M, Dominguez M, Schumann RR, Rauchhaus M, Poole-Wilson PA, Coats AJ, Anker SD: Endotoxin and immune activation in chronic heart failure: a prospective cohort study. Lancet 1999;353: 1838-1842.

-99 Sharma R, Bolger AP, Li W, Davlouros PA, Volk HD, Poole-Wilson PA, Coats AJ, Gatzoulis MA, Anker SD: Elevated circulating levels of inflammatory cytokines and bacterial endotoxin in adults with congenital heart disease. Am J Cardiol 2003;92:188-193.
00 Sandek A, Bjarnason I, Volk HD, Crane R, Meddings JB, Niebauer J, Kalra PR, Buhner S, Herrmann R, Springer J, Doehner W, von Haehling S, Anker SD, Rauchhaus M: Studies on bacterial endotoxin and intestinal absorption function in patients with chronic heart failure. Int J Cardiol 2012;157:80-85.

101 Rogler G, Rosano G: The heart and the gut. Eur Heart J 2014;35:426-430.

102 Maes M, Kubera M, Leunis JC: The gut-brain barrier in major depression: intestinal mucosal dysfunction with an increased translocation of LPS from Gram negative enterobacteria (leaky gut) plays a role in the inflammatory pathophysiology of depression. Neuro Endocrinol Lett 2008;29:117-124.

103 Berk M, Williams LJ, Jacka FN, O’Neil A, Pasco JA, Moylan S, Allen NB, Stuart AL, Hayley AC, Byrne ML, Maes M: So depression is an inflammatory disease, but where does the inflammation come from? BMC Med 2013;11:200.

104 Miller AH, Raison CL: The role of inflammation in depression: from evolutionary imperative to modern treatment target. Nat Rev Immunol 2015;16:22-34.

105 Brambilla P, Bellani M, Isola M, Bergami A, Marinelli V, Dusi N, Rambaldelli G, Tansella M, Finardi AM, Martino G, Perlini C, Furlan R: Increased M1/decreased M2 signature and signs of Th1/Th2 shift in chronic patients with bipolar disorder, but not in those with schizophrenia. Transl Psychiatry 2014;4:e406.

106 Drago A, Crisafulli C, Calabro M, Serretti A: Enrichment pathway analysis. The inflammatory genetic background in bipolar disorder. J Affect Disord 2015;179:88-94.

107 Mostafavi S, Battle A, Zhu X, Potash JB, et al: Type I interferon signaling genes in recurrent major depression: increased expression detected by whole-blood RNA sequencing. Mol Psychiatry 2014;19:1267-1274.

108 Pandey GN, Rizavi HS, Ren X, Fareed J, Hoppensteadt DA, Roberts RC, Conley RR, Dwivedi Y: Proinflammatory cytokines in the prefrontal cortex of teenage suicide victims. J Psychiatr Res 2012;46:57-63.

109 Pandey GN, Rizavi HS, Ren X, Bhaumik R, Dwivedi Y: Toll-like receptors in the depressed and suicide brain. J Psychiatr Res 2014;53:62-68.

110 Kanai T, Matsuoka K, Naganuma M, Hayashi A, Hisamatsu T: Diet, microbiota, and inflammatory bowel disease: lessons from Japanese foods. Korean J Intern Med 2014; 29:409-415.
Increased Intestinal Permeability and the Risk of Inflammation
Inflamm Intest Dis 2016;1:135-145 DOI: $10.1159 / 000447252$ 